\title{
(9)KELLOGG INSTITUTE
}

The Helen Kellogg Institute for International Studies

\section{NETWORKED JUSTICE: JUDGES, THE DIFFUSION OF IDEAS, AND LEGAL REFORM MOVEMENTS IN MEXICO}

\author{
Matthew C. Ingram * \\ Working Paper \#385 - June 2012
}

Matthew C. Ingram is assistant professor of political science at the University at Albany, State University of New York. His research examines justice sector reforms in Latin America, with work accepted for publication in Comparative Politics and the Journal of Law, Economics, and Organization. He was a 2011-12 visiting fellow at the Kellogg Institute for International Studies at the University of Notre Dame. Previously, Ingram was assistant professor of political science at the University of Massachusetts, Dartmouth, and a postdoctoral fellow at the Center for USMexican Studies at the University of California, San Diego (2009-2010). He holds a JD and PhD from the University of New Mexico, and worked in law enforcement in California for seven years (1994-2001) prior to graduate study. Ingram was born and raised in Mexico and speaks English, Spanish, and Portuguese.

*Prior drafts of this paper were presented at the 2012 meetings of the Midwest and Western Political Science Associations, the 2011 Political Networks conference, and the Kellogg Institute for International Studies, University of Notre Dame. I am grateful to Janet Box-Steffensmeier, Tom Ginsburg, Bettina Hollstein, Noam Lupu, Yonatan Lupu, Alexandra Marin, Steve Samford, Joseph Staats, and two anonymous reviewers for helpful comments. I am also grateful for ongoing collaborations with Lisa Hilbink, whose influence - in good network fashion - shaped many of the ideas presented here, and to James Fowler, for opening his research group during a fellowship at UC San Diego in 2009-2010. Lastly, I thank the judges of Michoacán: without their participation none of this would be possible. The University of Massachusetts Dartmouth Chancellor's Office and the Joseph P. Healey Endowment provided support for data collection. The Kellogg Institute provided writing support. 



\begin{abstract}
Existing research shows that the ideas of judges matter for judicial behavior both on the bench (decision making) and off the bench (lobbying and mobilization for institutional change). Yet there is little empirical evidence regarding the content and distribution of these ideas and even less evidence and fewer theoretical propositions regarding the manner in which ideas transfer or diffuse among judges. Addressing these empirical and theoretical gaps, I survey judges in the Mexican state of Michoacán and apply techniques of network analysis. The project makes four main contributions: (1) original data on the attitudes of judges regarding prominent institutional and jurisprudential changes shaping the legal landscape in Mexico; (2) egocentric data on network structure for the sampled judges; (3) sociocentric data on network structure at the level of judicial district, state supreme court, and entire state generated by aggregating the egocentric data; and (4) a mixed-methods analysis of the causal relationship between network features and judicial attitudes, drawing on egocentric methods, sociocentric methods, and personal interviews with focal individuals. Complementing literatures on political socialization, policy diffusion, and complex systems, the analysis clarifies our understanding of the role of judicial networks in strengthening democracy and the rule of law.
\end{abstract}

\title{
RESUMEN
}

Investigaciones existentes demuestran que las ideas de los jueces motivan el comportamiento judicial dentro de los juzgados (en la toma de decisiones) y fuera de estos (en el cabildeo institucional y las movilizaciones en torno a distintas reformas). Sin embargo, existe poca evidencia empírica en cuanto al contenido y la distribución de estas ideas, y aun menos evidencia y teorías sobre el modo en que las ideas se transfieren o difunden entre los jueces. Para dar cuenta de estas limitaciones empíricas y teóricas en la literatura, este trabajo desarrolla una encuesta a jueces en la entidad federativa mexicana de Michoacán, aplicando técnicas de análisis de redes. El proyecto hace cuatro contribuciones principales: (1) datos originales sobre las actitudes de jueces en cuanto a cambios importantes en las instituciones y la jurisprudencia que moldean el paisaje jurídico mexicano; (2) datos ego-céntricos sobre la estructura de redes entre los jueces encuestados; (3) datos socio-céntricos sobre la estructura de redes judiciales a nivel de distrito judicial, tribunal superior del estado, y el estado completo, los cuales se generan al agregar los datos ego-céntricos; y (4) un análisis basado en métodos mixtos de la relación causal entre las características de las redes y las actitudes judiciales, apoyándome en métodos ego-céntricos, socio-céntricos, y entrevistas personales con jueces. Complementando estudios sobre socialización política, la difusión de políticas públicas, y sistemas complejos, el análisis esclarece nuestro entendimiento sobre el papel de las redes judiciales en el fortalecimiento de la democracia y el estado de derecho. 



\section{INTRODUCTION}

Effective courts are widely regarded as vital to both democracy and development (O'Donnell 2001; UNDP 2004), and existing research in both judicial decision making and institutional change highlights the role of institutional insiders (judges) and their ideas in shaping key legal and judicial outcomes (Couso 2010; Hilbink 2007a, 2007b, 2009, 2012; Woods 2008, 2009; Woods and Hilbink 2009; Couso and Hilbink 2011; Rodríguez-Garavito 2011). That is, judges play pivotal roles in either helping or hindering processes of legal change depending on their attitudes towards that change.

Yet, despite the importance of judges' ideas for key judicial outcomes, we know very little about the content and distribution of these ideas, especially outside the United States, and even less about how these ideas transfer or diffuse among judges. How do ideas spread among judges? Why do different attitudes regarding institutional design, jurisprudence, and other forms of legal change diffuse among legal elites? Addressing these empirical and theoretical gaps, I conduct a network analysis of the diffusion of ideas among all judges in the Mexican state of Michoacán. Building on recent network analyses of the law (Fowler et al. 2007; Katz et al. 2011; Lupu and Voeten 2012), the project makes four main contributions: (1) original data on the attitudes of judges regarding prominent institutional and jurisprudential changes shaping the legal landscape in Mexico; (2) egocentric network data for the individual judges; (3) sociocentric network data for the whole state generated by aggregating the egocentric data; and (4) an analysis of the causal relationship between network structure and judicial attitudes. Indeed, the local level of analysis increases analytic leverage in the study of network dynamics (Sokhey and Djupe 2011) and also contributes to growing literatures on subnational politics (Snyder 2001; Beer 2003; Chavez 2004). Complementing literatures on political socialization, policy diffusion, and complex systems, I find a relationship between the social structure among judges and their attitudes, i.e., "networked justice." Given the vital role of judges and their ideas in shaping institutional design, jurisprudence, and other legal changes, a better understanding of this phenomenon clarifies the role of judges in strengthening democracy and the rule of law.

Looking ahead, I first motivate the emphasis on judicial networks by highlighting (1) the emphasis existing research places on the role of ideas in explaining key judicial 
outcomes and (2) how a network perspective can be harnessed to examine the origin and spread of these ideas. The following section introduces the reader to the landscape of legal change in Mexico, emphasizing the extent to which patterns seen in Mexico are illustrative of patterns seen elsewhere in the region and in other parts of the world. Subsequently, the fourth section outlines working hypotheses, and in the fifth section I present the data and introduce the sequence of methods. Notably, the egocentric, sociocentric, and qualitative portions of the analysis require different methods, and the approach to each of these phases is outlined separately in this section. The empirical analysis is concentrated in the sixth and seventh sections: the first part of the sixth section examines the egocentric data, and the second part analyzes the sociocentric data generated by aggregating the egocentric data; the seventh (and penultimate) section offers qualitative evidence from personal interviews with focal individuals. This mixed-methods approach draws on several streams of evidence and techniques, engaging in a process of data- and method-triangulation to maximize the validity of conclusions (Denzin 1978; Tarrow 1995).

Overall, I find consistent and robust evidence that social structure influences judicial attitudes. This is evident in the two different statistical approaches required to examine egocentric and sociocentric data, and in the qualitative component, as well. That is, the legal attitudes judges hold are shaped by those with whom they interact. In short, whom they know shapes what they know. I conclude with a discussion of broader implications and future research.

\section{WHY JUDICIAL NETWORKS?}

Ideas are a powerful predictor of judicial decisions and institutional change. In decision making — judicial behavior on the bench — attitudes, values, and ideology play a critical role in determining the willingness of judges to review particular cases, to address certain issues, and in determining the final outcome of cases. The US literature holds ample evidence of this phenomenon, perhaps most dramatically in the emphasis on political ideology in the "attitudinal model" of decision making (e.g., Segal and Spaeth 2002), also called "ideological voting" (Sunstein et al. 2004, 2006). Scholars of comparative judicial 
politics are increasingly finding similar results. ${ }^{1}$ Indeed, the comparative literature is moving beyond the US focus on political ideology, understood as an actor's placement along a conventional left-right continuum, to address other kinds of ideational variation among judges, including "judicial role conception" (Hilbink forthcoming 2012), understood as a judge's view of the appropriateness of challenging actions by dominant political actors (see also Couso 2010; Couso and Hilbink 2011).

In addition to shaping judicial decision making, ideational factors also motivate and shape the behavior of judges off the bench - activities of judges for and against institutional reforms. Evidence from the United States includes ideologically progressive, rights-oriented expansion and contraction of the judicial agenda (Epp 1998) and court jurisdiction (Gillman 2002, 2008). Comparative evidence includes variants of similar movements in Canada, Britain, and India (Epp 1998), neoliberal judicial elites in Israel, Canada, South Africa, and New Zealand (Hirschl 2000, 2004), and progressive judges in Spain (Hilbink 2007b), Israel (Woods 2008), Mexico (Ingram 2012b), and Brazil (Engelmann 2004; 2007; Ingram 2009). In sum, institutional insiders (judges) and their subjective, nonmaterial commitments play an important role in explaining crucial judicial outcomes. Judges can either help or hinder institutional design, jurisprudence, and other forms of legal change depending on how they conceptualize and think about said change.

Given the importance of judges and their ideas, the natural next move would be to consider what these ideas are and how one judge comes to hold them while another does not - where do ideas come from? Yet, while we know the ideas of judges matter, there is little empirical evidence regarding the content and distribution of these ideas and even less evidence regarding the how these ideas transfer or diffuse among judges.

First, we know very little about the content and distribution of judicial attitudes, especially outside the United States. That is, we know ideas matter and have a general sense of the kinds of ideas that matter, but little research to date has sought to systematically examine judges' attitudes about a range of institutional and jurisprudential

\footnotetext{
${ }^{1}$ Evidence includes studies in Brazil (Engelmann 2004; Desposato, Ingram, and Lannes 2011; see also Kapiszewski 2011, though she finds pragmatic considerations outweigh the influence of ideology), Chile (Hilbink 2007a, speaking of "institutional ideology"), Mexico (Sanchez, Magaloni, and Magar 2011), Colombia (Nunes 2010), and Portugal (Amaral-Garcia et al. 2009).
} 
issues. ${ }^{2}$ In part, this empirical gap is due to a degree of vagueness in the term "ideas," or what social movement scholars refer to as the "ephemeral, amorphous nature of the subject matter" (McAdam, McCarthy, and Zald 1996, 6, referring to the ideational framing process). To be clear, current research does operationalize attitudinal orientations among judges. For instance, several projects measure judicial ideology as a categorical variable capturing party affiliation and, therefore, ideology as the party of the appointing executive (e.g., Sunstein et al. 2004, 2006). In the United States, Segal-Cover scores improve on this method by examining newspaper editorials for each Supreme Court nominee and coding paragraphs as either liberal or conservative, yielding an index ( -1 to 1) for ideology (Segal and Cover 1989; Segal and Spaeth 2002). More recently, MartinQuinn scores draw on techniques developed for legislative roll-call analysis to generate estimates of judicial ideal points based on the actual votes of judges (Martin and Quinn 2002, 2007). Following the Martin-Quinn example, Desposato, Ingram, and Lannes (2011) estimate ideal points for justices on Brazil's constitutional court. While each of these metrics offers valuable and increasingly sophisticated contributions, they seek to place judges on a conventional left-right ideological spectrum, and some, like the MartinQuinn scores, rely on revealed preferences from behavior that may be highly strategic, in which case these measures may not coincide with sincere preferences. Further, these metrics do not ask judges themselves about their attitudes. Here, I conceptualize ideas specifically as attitudes towards existing legal reforms (e.g., the creation of judicial councils) and styles of decision making (e.g., whether lower-court judges should always have to defer to the decisions of higher courts). The survey questionnaire captures a wide range of attitudes regarding these institutional and jurisprudential topics and relies on judges' self reports to identify their attitudes.

Second, we know even less about how these attitudes transfer or diffuse among judges. The overwhelming majority of research treats judicial attitudes as an explanatory variable in a broad endeavor to understand the consequences of these attitudes for judicial behavior. Where attitudes do become an outcome of interest, studies tend to focus on static attributes or characteristics of actors as being the principal forces that shape ideas.

\footnotetext{
${ }^{2}$ Ingram, Rodriguez Ferreira, and Shirk (2011) survey judges, prosecutors, and public defenders' attitudes towards legal reforms in nine Mexican states.
} 
Ideational profiles are understood as the product of an individual's features, e.g., socioeconomic status. This may in fact be what is taking place. However, network analysis suggests that individual characteristics are only part of the story and that an individual's social relations and interactions with other individuals may account for a larger part of the origin of attitudes, values, and other ideas. Indeed, these relational dynamics may be most of the story.

Existing accounts tend to be qualitative and network approaches are generally absent, unclear, or implied. For instance, Couso (2010), Couso and Hilbink (2011), and Rodríguez-Garavito (2011) examine the emergence of different styles of judicial interpretation in the civil law world, from the traditional, technical formalism associated with legal positivism, to the rightist, market-oriented conservativism of "neoliberal constitutionalism," and the leftist, rights-oriented progressivism of "neoconstitutionalism" (see also Ferrajoli and Ruiz Manero 2012; Carbonell 2003; Langer 2007; González Gómez 2007; Cárdenas et al. 2010). To be clear, attention to relational sources of legal change and law reform networks is not new. Indeed, the idea of social networks and their influence is implicit in much social movement literature, including the legal mobilization scholarship in the United States and abroad (McCann 1994; Epp 1998; Hilbink 2007b; Woods 2008). For instance, Woods explains the emergence of "consensus around norms" $(2008,23)$ as the result of sustained interaction within relatively diffuse "judicial communities"-groups of judges who also share similar demographic characteristics such as education and professional trajectory. However, the treatment of network concepts is informal in the research cited above. ${ }^{3}$ Even where the notion of networks and diffusion effects are referenced more explicitly, network concepts remain largely informal (e.g., Langer 2007; Rodríguez-Garavito 2011; Ingram 2012b).

More recently, a small number of scholars have framed the explanation of the diffusion of legal ideas in explicitly structural, network analytic terms, harnessing a fuller set of conceptual, measurement, and analytic techniques for the study of judicial networks. Fowler et al. (2007) and Fowler and Jeon (2008) examine citation networks of

\footnotetext{
${ }^{3}$ For instance, a "justice network" (red de justicia) might be a group of interested individuals or an informal association of groups, not a formal, structural representation of a network.
} 
US Supreme Court precedents, identifying the most central or influential cases. Similarly, Lupu and Voeten (2012) examine the citation networks of the European Court of Human Rights. In international relations, Fariss and Schnakenberg (2009) apply network analysis to the study of human rights regimes and the incidence of torture. Back in the United States, Katz and Stafford (2010) use law clerks to proxy relations among US federal judges, constructing a network of the connectedness of the federal judiciary and operationalizing judicial authority or power according to the structural location of actors in this network. Closely related to the present study of ideational contagion among judges, Katz et al. (2011) examine the "infectiousness of ideas" among the professoriate in 184 ABA-accredited law schools in the United States. Using measures of network centrality, they conclude that law schools that send more of their graduates to tenuretrack positions at other law schools become "hubs" of legal influence, establishing the hierarchical structure of legal education. The architecture of these relations serves as the conduit for diffusing legal ideas, much as I propose that the architecture of relations among judges shapes the diffusion of ideas regarding reform.

Indeed, network analysis is a particularly powerful approach for examining the diffusion of ideas. For instance, conventional data sets and statistical techniques view units as independent of each other. That is, judges' attitudes are seen as a function of their own individual attributes (e.g., age, sex, education, income), and perhaps some contextual events (e.g., financial crisis), but not as a function of their colleagues' attitudes, which would violate the independence assumption underlying most analyses. Thus, the adoption of a new idea is fundamentally understood as an individualistic or atomistic phenomenon, based on the properties, features, or attributes of the individual. Conversely, a network perspective conceptualizes units of analysis as interdependent; judicial attitudes may be shaped in part by individual attributes, but they are also a function of the attitudes of other judges. One's attitude is explicitly dependent on the attitude of one's neighbors! Echoing Woods and earlier social movement theory, ideas spread among individuals who are in "intense regular contact with each other" (Ferree and Miller 1977, 34; cited in McAdam, McCarthy, and Zald 1996, 9). Thus, a long line of research applies network analysis to problems and puzzles of diffusion, contagion, and innovation, finding that "an individual's direct contacts influence his or her decision to adopt or not adopt an 
innovation" (Valente 1995, 31). In the present study, said innovation is ideationaladopting an attitude because one's direct contacts hold that attitude. To be clear, this does not mean that individual attributes or other contextual effects do not matter. They surely do. However, individual and contextual effects may not be the whole story, or they may be a smaller part of the story than previously conceived, if we account for the spread of ideas as being at least partially driven by close interactions and relations.

\section{JUDICIAL REFORM NETWORKS IN MEXICO}

Mexico offers a rich environment in which to study justice reform networks. Historically suffering from weak and dysfunctional courts (see, e.g., Cumaraswamy 2002), in the last twenty years - through a slow political opening starting in 1977 and after a transition to democracy in 2000-Mexico has advanced several high-profile reforms to address the widely recognized weakness of justice institutions. The two most prominent reforms target judicial councils and criminal procedure. First, a national reform in 1994 reshaped the supreme court and created a federal judicial council (Fix-Zamudio and Fix-Fierro 1996; Fix-Fierro 2003, 2004; Finkel 2008). Mexico's thirty-two states were supposed to follow suit, but there was no explicit directive to do so. Second, following regional developments in criminal law (Langer 2007), a 2008 criminal procedure reform has revolutionized the way Mexican judges think about criminal procedure and due process, transitioning from an inquisitorial process traditionally associated with civil law systems to an adversarial process associated with common law systems (Ingram and Shirk 2010). This time, the federal reform mandated that all thirty-two states (including the federal district of Mexico City) adopt local versions of the new criminal procedure by 2016. Both reforms have filtered through the states in a highly uneven pattern (Ingram 2012a, 2012b).

Beyond critical reforms that deserve attention for their substantive importance, (Ingram 2012b) offers qualitative evidence of judges who act as reform entrepreneurs or agents of socialization, constituting the kind of justice reform networks the present study seeks to formalize in a more systematic manner. For instance, a group of judges from the state of Michoacán formed a close-knit group that promoted the judicial council reform in that state from 2002 onwards, and members of this group have since also promoted the 
criminal procedure reform. The judicial council reform was ultimately passed in 2005, and on January 13, 2012, the state passed the vital new code of criminal procedure. Several members of this group, led by state supreme court judge Alejandro González Gómez and state electoral judge Jaime del Rio, studied law together in Spain at the Universidad Complutense de Madrid and were influenced by the teachings and experiences of progressive judges who lived through Spain's transition from Franco's dictatorship to democracy in the late 1970s and 1980s, including the "Democratic Justice" movement examined by Hilbink (2007b). Further, judges like Alejandro González also had academic careers - either before joining the bench or after-and interviews conducted in 2008 and 2012 showed that exposure to these individuals' academic and professional presence influenced colleagues and newer generations of legal professionals.

On case selection, Michoacán is a good case for both methodological and nonmethodological reasons. First, early on there were fair questions about the feasibility of this kind of project. A network approach to ideational diffusion among judges is novel, and it was reasonable to expect that judges might not be willing to answer questions about their relational structure, so the ability to generate original data for the project at first seemed unlikely, especially in a less developed country facing serious challenges in public safety and security. Thus, it made sense to start somewhere where prior work indicated at least some form of network influence, even if informally. My own prior research provided this with regard to the group of judges that formed around Alejandro González and Jaime Del Rio. Thus, the research design returns to a site of prior research for a more systematic examination of how relations among judges shape their ideas. Further, given the breadth and depth of legal reforms being pursued in Mexico, the country offers a rich environment in which to study the diffusion of ideas among judges that might help or hinder such a process. However, as in many larger federal systems, the implementation of many reforms in Mexico-including the judicial council and criminal procedure reforms - are left to the states. Many states have not promoted these reforms, while others have advanced far. In this regard, a good state in which to conduct this research is one in which there is some evidence of variation in the attitudes of judges towards these reforms. Again, Michoacán provides this variation to a much greater 
degree than other states. For instance, the judicial council reform of 2005 was a highly contested process, due in part to a deep division among judges regarding the composition and powers of the council. Lastly, methodological reasons justify the focus on diffusion within a single state or geographic region. As noted by a recent review of network research, "instead of worrying about national representativeness, progress may come from in-depth study in smaller settings" (Sokhey and Djupe 2011, 58).

\section{HYPOTHESES}

The discussion above leads to the general expectation that judges who interact more intensely, more frequently, and are otherwise more "connected" within their profession and legal community will share similar normative outlooks about legal and institutional change. These judges and their connections constitute what I call "justice reform networks." By understanding the relational sources of judges' ideas, we can understand the social origins of strong courts, or "networked justice."

Specifically, I expect to find evidence showing: (1) variation in the content of judges' opinions regarding a variety of recent and ongoing reforms; (2) variation in the structure of relations among judges; and (3) a causal relationships between the structure of judges' relations on their opinions about justice reforms. That is, whom judges know affects what they know. I anticipate the following working hypotheses.

H1a: In ego networks, attitude towards reform should vary positively with network size and density.

H1b: In whole networks, attitude towards reform should vary positively with how "central" one's social location is in the whole network.

H2: Attitude towards reform should vary positively with the attitude(s) of network neighbor(s).

H3: Hypothesis 2 should be conditioned by the strength of relations among network neighbors.

Regarding H1a and H1b, measures of network size and density, as well as various measures of network centrality, draw on existing literature. Network size is simply the number of alters in any ego network, and network density captures the number of existing 
ties as a proportion of the total possible ties. Network centrality can be unpacked into at least four distinct forms of centrality: degree, betweenness, closeness, and eigenvector centrality. Degree centrality is the total number of ties for each node. Degree centrality is therefore analogous to network size, except that in the ego network analysis the range is one to five (1-5), whereas in the sociocentric analysis the range is much larger.

Betweenness centrality captures the extent to which a node is on the shortest path between two other nodes. Nodes with high values on this measure are often thought of as being good conduits, bridges, brokers, or gatekeepers between other nodes. Because more information should flow through these nodes than others with lower values, these nodes are exposed to more information and should therefore adopt new ideas and attitudes faster or sooner than others. Closeness centrality captures the ease with which a node can reach all other nodes in the network. High values on any of these measures indicate that the individual is "more likely to receive information and influence" (Valente 1995, 53). Therefore, these measures should be associated with "innovativeness" or in the case of ideational diffusion, the adoption of new ideas.

\section{METHODS AND DATA}

\section{Network Analysis}

The network perspective requires a shift from focusing on the attributes of independent units to a focus on the relational ties among these units, rendering the structure of data explicitly dependent. This analytic shift has implications for descriptive and causal analysis.

Networks are usually studied as either (1) whole networks (also called “sociocentric"), or (2) personal or "ego" networks (also called "egocentric"). Each approach has its strengths and weaknesses. In whole networks, a boundary establishes the outer perimeter of the network (e.g., a classroom), and information must be collected on every single member within that perimeter (e.g., every student in class) and on the ties between that member and every other member. Strengths of this approach include a full set of relational ties provided or reported by each member of the network. In generating original survey-based data, this high information requirement means the survey sample 
must consist of the full population of the network. A weakness of this approach is that the boundary is almost always set arbitrarily, so relations beyond this arbitrary boundary are left out. For instance, a "whole" classroom network is imbedded within a larger school network, but the data collection strategy treats these other relations as absent. Another weakness is that gathering data on all relational ties becomes increasingly difficult as network size increases; thus, this approach is infeasible with networks larger than approximately a hundred members.

In contrast, personal networks examine one individual (the "ego") and the quantity and quality of relations with others ("alters"), and samples of egos can be selected rather than requiring the full population (Wasserman and Faust 1994; Hanneman and Riddle 2005). All the information about the network comes from the ego; that is, the ego reports her or his own opinions and identifies the people with whom she or he interacts. This information provides the size of the personal network, and the ego then reports on the characteristics of alters, the quality of the ego's tie with each alter, and on ties among alters. The accuracy of the ego's responses regarding alters and alter-alter relations is not that important; since the analysis examines the influence of the network on the ego at its center, ego's subjective perception of the qualities of alters and of their relations matters more than objective accuracy (Sinclair in Fowler et al. 2011). Strengths of this method include the ease of implementation in survey analysis (network batteries) or interviews. Weaknesses include the fact each personal network is almost certainly larger than any survey could capture, so relevant ties may be lost, and the ego network cannot be studied as part of a broader society. Table 1 summarize the trade-offs between these two approaches. 
TABLE 1

TRADE-OFFS BETWEEN EGO- AND SOCIOCENTRIC DATA

\begin{tabular}{lll}
\hline \multicolumn{1}{c}{ Ego } & \multicolumn{1}{c}{ Socio } \\
\hline Strengths & $\begin{array}{l}\text { Easier to collect own data from } \\
\text { medium-sized and large } \\
\text { populations }\end{array}$ & Can see broader group or society \\
& $\begin{array}{l}\text { Statistical analysis is more } \\
\text { straightforward }\end{array}$ & $\begin{array}{l}\text { Can estimate network features and } \\
\text { effects across broader } \\
\text { group/society }\end{array}$ \\
\hline Weaknesses & $\begin{array}{l}\text { Lack sense of connectedness } \\
\text { within broader group or society }\end{array}$ & $\begin{array}{l}\text { Harder to collect original personal } \\
\text { data }\end{array}$ \\
& $\begin{array}{l}\text { Sampling may not yield } \\
\text { independent observations (always } \\
\text { true to at least some degree, } \\
\text { especially if take idea of "small } \\
\text { worlds" seriously) }\end{array}$ & $\begin{array}{l}\text { Network boundary can be } \\
\text { arbitrary-not clear that it } \\
\text { corresponds with reality; i.e., } \\
\text { cannot see others who might exert } \\
\text { influence }\end{array}$ \\
& & \begin{tabular}{l} 
Statistical analysis is more difficult \\
\hline
\end{tabular} \\
\hline
\end{tabular}

No single method is perfect, so relying on a multi-method approach leverages the “diversity of imperfections” (Brewer and Hunter 1989, 16-17; also Tashakkori and Teddlie 1998, 40-42) to strengthen the validity of conclusions. To this end, I employ a mixed-methods strategy in two ways: (1) in the combination of ego (egocentric) and whole (sociocentric) network data and analysis; and (2) in the combination of quantitative and qualitative methods. First, I examine only the egocentric data. Since each ego network is sampled independently of the others, these data can be studied with standard regression techniques that treat each observation as independent. Given the ordinal nature of the response variable, an ordered probabilistic regression model is applied. Second, I aggregate the egocentric data to form sociocentric networks, thereby drawing on the strengths of each type of data to offset their weaknesses in Table 1 above.

The quantitative analysis of network influence in sociocentric networks focuses on two approaches: (1) network disturbance models, and (2) network effects models. Network disturbance models (Dow 1979, 1984; Dow et al. 1982) derived from geographic, spatial analysis have been popular for several decades. However, Leenders (2002) and Dow $(2007,346)$ highlight that autocorrelation in the error (i.e., disturbance) 
term can be due to at least three different sources: incorrect model specification (e.g., linear vs. nonlinear), omitted variable(s), or adjustment to perceived values in an ego's social context. It is only this last influence that is properly a network influence. Even here, however, the model conceptualizes influence more as reaction than interaction (Leenders 2002, cited in Dow 2007, 346). For this reason, Dow $(2007,346)$ notes that the network effects model may be more appropriate than the network disturbance model, though extensions including both types of influence are also possible (e.g., Dow 2007, 344; Butts 2008, 39). ${ }^{4}$

Given the ordinal response variable and following Dow (2007, 2008), I employ a two-stage, conditional maximum likelihood (2SCML) network autocorrelation effects model. Equations (1) and (2) represent the initial structural model in matrix notation:

$$
\begin{gathered}
y=\rho W y+X_{1} \beta_{1}+\varepsilon \\
W y=X_{2} \beta_{2}+v
\end{gathered}
$$

where $\boldsymbol{y}$ is a $N x 1$ vector of the ordinal outcome of interest, $\boldsymbol{W}$ is a square $N x N$ weights matrix that specifies the presence (binary matrix; hereafter referred to as W1) or strength (valued matrix, referred to as W2) of relations among all dyads of judges; $\boldsymbol{X}$ is an $N x k$ matrix of explanatory variables, $\boldsymbol{\varepsilon}$ and $\boldsymbol{v}$ are vectors of error terms, and $\boldsymbol{\rho}$ and $\boldsymbol{\beta}$ are vectors of regression coefficients. Thus, $\boldsymbol{W} \boldsymbol{y}$ captures the multiplication between $\boldsymbol{W}$ and $\boldsymbol{y}$ that yields a vector of the weighted average of the quantity $\boldsymbol{y}$ among an individual's social relations. Equations (1) and (2) reduce to equation (3) below,

$$
\mathbf{y}=\rho \mathbf{W y}+\mathbf{X}_{1} \beta_{1}+\lambda v+\eta
$$

\footnotetext{
${ }^{4}$ In R, the "Inam" function in the "sna" package allows the specification of two weight matrices, $\mathrm{W} 1$ and W2, where W1 is a vector of autoregressive (AR) or network effects parameters, and W2 is a vector of moving average (MA) or network disturbance parameters (Butts 2008).
} 
where $\boldsymbol{\eta}=\boldsymbol{\varepsilon}-\boldsymbol{\lambda} \boldsymbol{v}$. Regressing $\boldsymbol{W} \boldsymbol{y}$ on instrumental variables ${ }^{5}$ yields residuals $\boldsymbol{v}$, which can be plugged into Equation (3) (see Dow 2008 for detailed discussion of method).

Lastly, the research design combines these two forms of quantitative network analysis (personal and whole) with in-depth, qualitative network analysis. Following Hollstein (2011), I sequence the qualitative phase of work after the quantitative phase, selecting five judges for personal, semi-structured interviews using qualitative network techniques. The triangulation of data and methods inherent in the combination of methods enhances the validity of both the measures and the final conclusions regarding causation (Hollstein 2011; see also Padgett in Fowler et al. 2011).

\section{Data}

A survey of judges in the Mexican state of Michoacán generated original data for this study. The state has a total of 110 judges, including first-instance jueces and secondinstance magistrados. Of this total, a primary effort of telephonic contacts sought a full census of these judges but obtained eighty-five responses. A follow-up effort via email obtained an additional five responses, yielding a total of ninety completed questionnaires, for a response rate of 81.82 percent. ${ }^{6}$ Once the initial data analysis was complete, personal interviews with five focal individuals were conducted in the state capital, Morelia, in January 2012.

The survey instrument consists of three batteries: (1) opinion, (2) "name generator," and (3) "name interpreter." Opinion questions register the attitudes of the respondent (ego) towards a series of recent and ongoing legal and institutional reforms, asking egos to gauge the degree to which they agree with a statement, following a Likert

\footnotetext{
${ }^{5}$ Dow notes that the "ideal set of instruments for the spatial (and thus also network) effects model are the linear combinations of the exogenous variables X1 [in equation 1] and powers of the network weights matrix (Dow 2008, 402, citing Kelejian and Prucha 1998; see also Dow 2008, fn. 8). I use linear combinations of $\mathrm{W}$ and the exogenous variables sex, position, and judicial district. On use of instruments in network regressions, see also Huckfeldt and Sprague (1987; 1993).

${ }^{6}$ The polling firm Data Opinión Pública y Mercados (DataOPM), based in Mexico City, conducted the telephonic interviews in June and July 2011. At DataOPM, Pablo Parás and Carlos López managed the survey administration, and both have conducted previous surveys in the justice sector in Mexico. I am grateful to them both and to their staff for valuable feedback on early drafts of the questionnaire and for communications during the survey administration that enhanced its feasibility and interpretation.
} 
scale $(1=$ strongly disagree, $5=$ strongly agree $)$. For instance, sample questions include statements such as "the reform that created the judicial council was a good idea" and "lower court judges can diverge from the decisions of higher courts." In the second battery, "name generator" questions ask egos to identify up to ten people with whom they "discuss important matters relating to legal and judicial reforms." This phrasing is borrowed from established surveys that seek to identify the individuals with whom the ego most interacts on particular subject matters (e.g., network batteries in the United States from General Social Survey, GSS, or American National Election Studies, ANES). Egos also identify how "close" they feel to each alter, providing a metric for tie strength. Lastly, respondents are asked to focus on the first five names they provided, and "name interpreter" questions ask egos a series of questions about each of these five alters. ${ }^{7}$ Name interpreter questions include those that ask ego to estimate how each alter would respond to each of the opinion questions asked previously of ego, whether the alters know each other, and how close alters are to each other. These answers provide a sense of the attitudinal orientation of alters, network structure, and tie strength among alters.

The survey yields two types of network data: egocentric and sociocentric. First, following Müller, Wellman, and Marin (1999), I construct two data sets: one with egos' demographic data and own attitudes (unit of analysis is the ego), and one with tie-wise data based on egos' reported alters and alters' attitudes. I aggregate alter attributes in the second, tie-wise data set. This portion of the analysis yields total network size and mean closeness. Further, the aggregate measures for each of the attitudinal variables capture network composition. I merge these data with the first data set of ego attributes, yielding a combined data set where the unit of observation is each personal network. ${ }^{8}$ Importing relational data among alters into UCINET, I extract further data on each ego network based on more detailed information on the first five alters listed in the name generator questions. Variables capturing network structure include degree (i.e., size), density, and average tie strength. Degree captures the general connectedness of the ego, with higher

\footnotetext{
${ }^{7}$ Burt (1984) considered the number of alters for the network battery included in the US General Social Survey (GSS); he suggested three as a minimum number, and ultimately decided on five, citing evidence that people can only hold five to seven significant "data chunks" in their head at any one time (citing Miller 1956; Simon 1974).

${ }^{8}$ This portion of analysis used SPSS Statistics 19 (Data $\rightarrow$ Aggregate function with "netid" as the break variable; Data $\rightarrow$ Merge Files $\rightarrow$ Add Variables).
} 
values indicating greater integration into the society of judges. Density captures the number of ties among alters as a proportion of the total number of possible ties among them, measuring the extent to which an ego's alters know and communicate with each other. Higher numbers indicate more connectivity within the personal network (Valente $1995,40) .{ }^{9}$ Tie strength was measured by asking respondents how close they were to each alter and how close each of the alters were to each other (cercanía). Closeness, along with UCINET's output for network density, are useful measures of the cohesiveness of each ego network (Hanneman and Riddle 2005, chap. 8). ${ }^{10}$ Following Betsy Sinclair's advice in Fowler et al. (2011), additional variables must control for homophily and confounders that might be ascribed to context. Homophily is the similarity between nodes on individual attributes that might cause these individuals to have the attitude of interest. Thus, control variables include age, progressiveness, ideological orientation, highest level of education, income, professional position, and judicial district. Regarding age, there is reason to expect that younger judges may be more open to institutional and jurisprudential changes. Interview evidence suggests judicial elders are resistant to legal change because these changes tend to require a new way of performing their job, something they are disinclined to do late in their careers. Therefore, I expect age to be negatively related to attitude. Further, the dummy variable for position distinguishes first- from second-instance, appellate judges ( 1 if second-

\footnotetext{
${ }^{9}$ High density may also impede the entrance of new ideas (Danowski 1986, cited in Valente 1995, 40).

${ }^{10}$ UCINET generates additional measures of network structure, but they are omitted here for various reasons. Of these other measures, "brokerage" and "betweenness" offer different ways of "indexing just how 'central' or 'powerful' ego is within their own neighborhood," and structural holes offer a way of measuring structural inequalities (Hanneman and Riddle 2005, chap. 9). "Reach" is dropped because these ego networks are not extracted from a larger, complete network. Rather, they are collected individually. However, if a sufficient number of ego networks were collected so that a full network could be generated from the aggregation of the personal cases, then this calculation could be examined. Indeed, that is part of the research design and ongoing data collection effort.

Additionally, there are no weak components, or rather, ego is imbedded in a single weak component. That is, there are no groups of alters for which ego is the only connection to other alters. For this reason, UCINET reports " 1 " for this variable. Given the single component for each of network, normalizing by network size is not done (normalizing "is a pretty meaningless exercise" if there are no cases of multiple components among the examined networks, see, e.g., Hanneman and Riddle 2005, chap. 9). A more detailed analysis of Gould and Fernandez brokerage roles is possible (i.e., coordinator, consultant, gatekeeper, etc.), but is beyond the scope of this paper.
} 
instance magistrado, 0 if first-instance juez). I anticipate that income and position capture seniority, which should also have a negative relationship with attitude.

Ultimately, the opinions of alters establish the composition of ego's network, and the remaining questions establish the structure of each personal network. Figure 1 visualizes two of these ego networks - one with many alters and ties among alters and one with few alters and ties among them — which also convey the structural inequalities described above. ${ }^{11}$ In Figure 1, node size varies according to degree and the width of edges between nodes varies according to tie strength. By definition of the ego network, the ego is connected to all alters, so the ego node and all ego-alter ties are in light grey in the background. Table 2 summarizes descriptive statistics for ego's attitude on four issues, network composition on these issues (alters' mean attitude), ego's demographic characteristics, and structural features of personal network.

FIGURE 1

\section{ILLUSTRATIONS OF EGO NETWORKS}
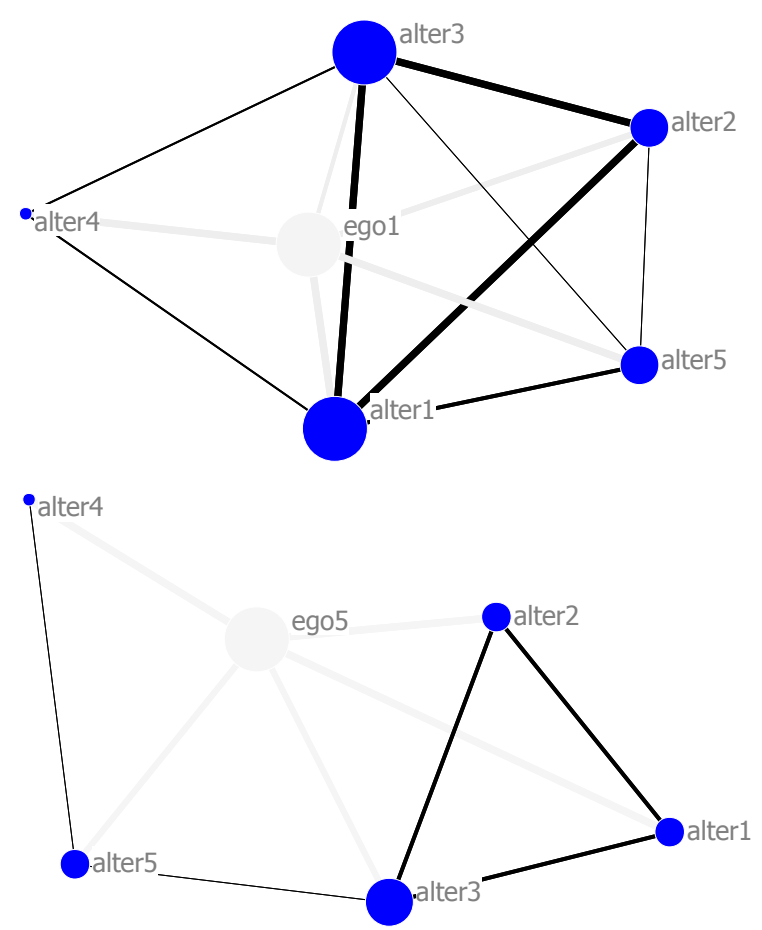

${ }^{11}$ Visualizations generated in UCINET (Borgatti, Everett, and Freeman 1999). 
TABLE 2

DESCRIPTIVE STATISTICS FOR EGOCENTRIC DATA

\begin{tabular}{lccccc}
\hline Variable & N & Mean & S.D. & Min & Max \\
\hline Ego Attitudes & & & & & \\
\hline Judicial Councils & 78 & 4.24 & 1.20 & 1 & 5 \\
Criminal Procedure & 71 & 3.97 & 1.19 & 1 & 5 \\
Same Sex Marriage & 78 & 3.36 & 1.64 & 1 & 5 \\
Deference to Higher Courts & 78 & 3.58 & 1.62 & 1 & 5 \\
Positivism & 78 & 4.08 & 1.10 & 1 & 5 \\
Military Jurisdiction & 78 & 2.58 & 1.51 & 1 & 5 \\
\hline Network Composition (mean alter attitude) & & & & \\
\hline Judicial Councils & 78 & 4.25 & 0.91 & 1.67 & 5 \\
Criminal Procedure & 76 & 4.12 & 0.87 & 2 & 5 \\
Same Sex Marriage & 74 & 2.96 & 1.38 & 1 & 5 \\
Deference to Higher Courts & 76 & 3.54 & 1.37 & 1 & 5 \\
Positivism & 76 & 3.95 & 1.01 & 1 & 5 \\
Military Jurisdiction & 74 & 2.73 & 1.25 & 1 & 5 \\
\hline Network Structure & & & & & \\
\hline Size & 78 & 2.81 & 1.15 & 1 & 5 \\
Density & 78 & 0.37 & 0.20 & 0 & 50 \\
closeness (mean tie strength) & 78 & 3.99 & 0.87 & 1 & 5 \\
\hline Ego Demographic Data & & & & 2 & 7 \\
\hline Progressive & 78 & 6.10 & 1.03 & 2 & 3 \\
Education (highest level) & 78 & 2.47 & 0.80 & 1 & 1 \\
Female & 78 & 0.31 & 0.46 & 0 & 62 \\
Age & 78 & 44.18 & 7.42 & 32 & 2 \\
Salary & 76 & 4.78 & 1.31 & 2 & \\
\hline & & & & & \\
\hline
\end{tabular}

Next, I aggregate the egocentric data to generate socio-network data. Given that the survey targeted all judges in the state, it is reasonable to conclude that some of these judges will be listing each other as alters. For instance, in the figure above, ego1's alter5 may be ego5's alter4, or even ego5 herself; thus, we get a fuller sense of the structure of social relations between these two judges by finding the ways in which their social structure overlaps. If we do this for all respondents, aggregating all the ego networks according to alter-alter matches or ego-alter matches and restricting the inclusion only to judges, the result is a whole, sociocentric data set of 113 judges in the state of Michoacán (113 is more than the 110 judges listed on the official directory of judiciary, but this 
directory does not account for recent personnel changes: indeed, the consultant who administered the survey noted that in calls to several courts the interviewer was turned away because a judge had either been reassigned or no judge had yet been assigned to the court; in other cases, a new judge not yet on the official roster/directory was already there and completed the questionnaire. So the name generator battery of the survey yields three additional individuals identified as judges by their peers). Thus, for all practical purposes, we have a full network of all judges. The attitudes of judges who did not participate in the survey are established by averaging the responses provided by participants (recall that all participants provided their own opinions in the first part of the survey and then provided an estimate of their alters' opinions in the name interpreter battery). After removing isolates and a number of observations that were missing data, the full network consists of 102 nodes with varying demographic and attitudinal characteristics and 290 edges of varying strength. The 102 nodes constitute 92.73 percent of the 110 on the official directory of judges. In addition to the full network of all state judges, these aggregated data include 18 of 19 magistrados on the state supreme court ( 94.64 percent complete), and 47 of the 49 judges (95.92 percent complete) in the judicial district of the capital, Morelia (including magistrados, who are based there). Though a purist would consider these networks to be technically incomplete, they are very nearly complete, and existing research includes examples of sociocentric analysis on networks ranging in completeness from 65.3 percent to 77.7 percent (e.g., Berardo 2011, 69). Thus, beyond the egocentric networks above, the aggregation process yields three different sociocentric networks based on three distinct boundaries in increasing order of size: state supreme court, judicial district of Morelia, and state. Figure 2 visualizes the largest of these networks, which is also the target of analysis in the quantitative section below. Node size is based on number of ties (degree centrality); edge color reflects tie strength (strongest in black); and node color reflects attitude towards judicial councils (low to high passing from blue, through yellow, to red). ${ }^{12}$ Table 3 summarizes statistics for this sociocentric network.

\footnotetext{
${ }^{12}$ Whole network visualizations generated using Cytoscape 2.8.2 (Smoot et al. 2011).
} 
FIGURE 2

\section{FULL NETWORK OF JUDGES IN MICHOACÁN}

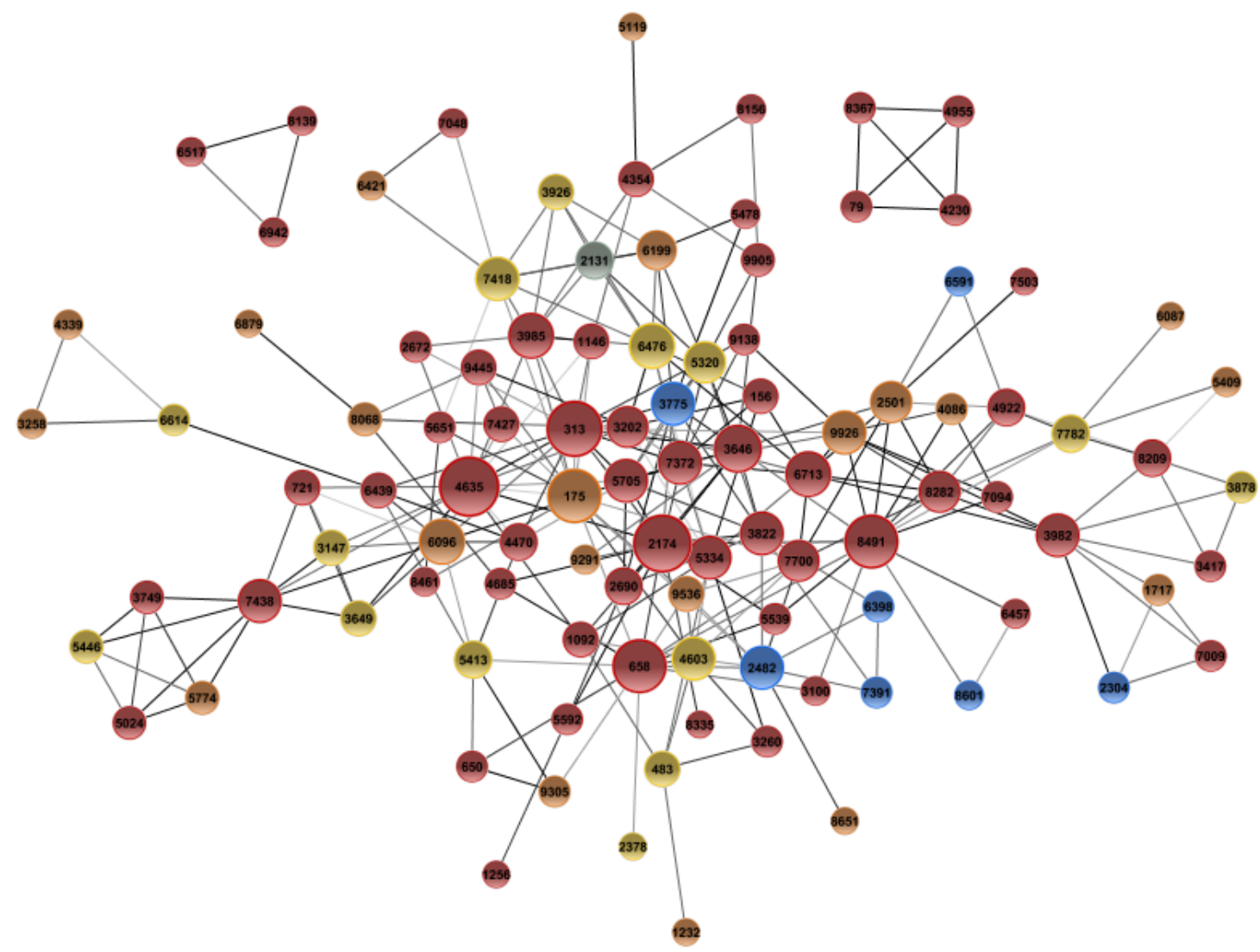

TABLE 3

DESCRIPTIVE STATISTICS FOR SOCIOCENTRIC DATA

\begin{tabular}{lccccc}
\hline Variable & N & Mean & S.D. & Min & Max \\
\hline Ego Attitude (Judicial Councils) & 102 & 4.22 & 1.16 & 1 & 5 \\
Network Weighted Mean & 102 & 3.13 & 0.93 & 0.80 & 5.00 \\
Female & 102 & 0.31 & 0.47 & 0 & 1 \\
Magistrado & 102 & 0.18 & 0.38 & 0 & 1 \\
Morelia & 102 & 0.46 & 0.50 & 0 & 1 \\
Degree & 102 & 5.18 & 3.67 & 1 & 17 \\
Betweenness & 102 & 100.30 & 172.04 & 0.00 & 748.39 \\
Closeness & 102 & 1744 & 2292 & 1030 & 10202 \\
Eigenvector & 102 & 0.07 & 0.07 & 0.00 & 0.30 \\
\hline
\end{tabular}


In the sociocentric analysis of the network represented in Figure 2, the key explanatory variable is the mean value of the attitude of each of a node's neighbors. Additional explanatory variables operationalize centrality in the overall network, homophily, and context. The analysis includes four measures of centrality: degree, betweenness, closeness, and eigenvector centrality. The entire network is treated as undirected, so all incoming and outgoing ties are treated equally. Measures of centrality are based on this undirected network, and all measures were generated in UCINET (Borgatti, Everett, and Freeman 1999).

\section{RESULTS}

\section{Results 1: Egocentric Networks}

Given the ordinal dependent variable (ego's attitude), I applied ordered probabilistic regressions to the egocentric data. The main explanatory variable is the mean value of the attitude among the ego's alters, capturing the attitudinal composition of the network. This model approximates what Valente (1995, 43-45) called a "personal network exposure" model of diffusion.

Focusing on attitudes towards judicial councils, the partial correlation between ego's attitude and alters' mean attitude is $0.68(\mathrm{p}<0.01)$. Table 4 summarizes the regression results. First, ordered logistic regressions must meet the parallel regression assumption, also called the probabilistic odds assumption. That is, ordered probit (and logit) assume that the effect of the explanatory variables (X) across all levels of the response variable $(\mathrm{Y})$ is the same, i.e., the size of the coefficients does not change for different values of Y. A likelihood ratio test implemented at the bottom of each column shows whether the analysis meets that assumption. ${ }^{13}$

\footnotetext{
${ }^{13}$ Test was implemented using omodel in Stata v.11. See also Dow $(2008,407)$ and Stata Data Analysis Examples: Ordered Logistic Regression, UCLA: Academic Technology Services, Statistical Consulting Group. Available at: http://www.ats.ucla.edu/stat/stata/output/stata_ologit_output.htm (last accessed February 23, 2012).
} 
TABLE 4

PERSONAL NETWORKS; ORDERED PROBABILISTIC REGRESSION Y = ATTITUDES TOWARDS JUDICIAL COUNCILS (1-5)

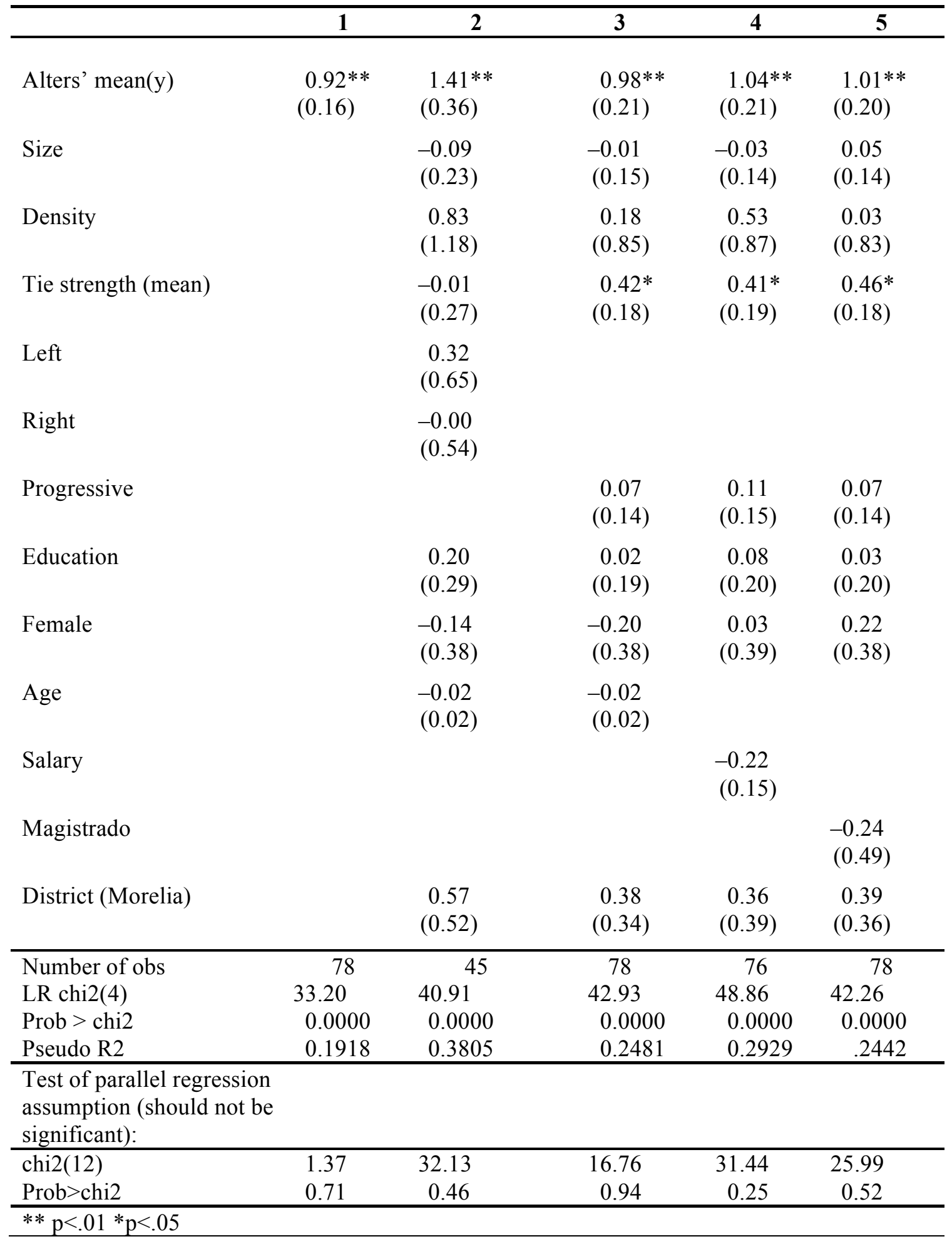


The key predictor-alter's mean(y) — has the expected positive relationship with ego's attitude, and this result is statistically significant. Similarly, mean tie strength has a positive and statistically significant relationship. These core results hold while controlling for other aspects of network structure, demographic variables, and judicial district, none of which are significant. Indeed, the substantive effect of alters' attitudes increases as the controls are added. ${ }^{14}$

Figure 3 clarifies the substantive significance of the main result. Based on Model 5 , each plot graphs the predicted probability of each outcome (1-5) sequentially against alters' mean attitude, shading the area between the upper and lower bounds of the 95 percent confidence interval. ${ }^{15}$ The probability of the lowest attitude $(\mathrm{y}=1)$ is highest where alters' mean attitude is at its lowest; in this instance, there is about a 87 percent likelihood that ego's attitude has the lowest value if alters' mean is at its lowest value $(\operatorname{Pr}(\mathrm{y} \mid \mathrm{x})=\operatorname{Pr}(1 \mid 1)=.87)$, and this likelihood declines rapidly as alters' attitude increases. Conversely, there is approximately a 90 percent likelihood of the highest outcome ( $y=5)$ if mean $(y)$ is also at its highest value. This likelihood drops precipitously if mean $(y)$ decreases, to 60 percent if mean $(y)=4$, and to only 20 percent if mean $(y)=3$. In short, a judge's attitude towards judicial councils is shaped by his or her colleagues' attitudes towards councils. Taken in combination with the finding regarding tie strength, this is systematic, empirical support for the proposition that intense interaction, a la Ferree and Miller (1977), promotes ideational diffusion. Contrast with Woods's (2008) proposition that diffuse connections characterize "judicial communities" that generate ideational consensus; though the role of "weak ties" inherent in her account is not directly tested here, the positive and significant effect of tie strength cuts against that argument.

\footnotetext{
${ }^{14}$ Age, salary, and position (magistrado dummy) are theoretically capturing similar dynamics, and magistrado and salary are empirically correlated (0.66), so they are not included in the same model. Still, including (1) age and magistrado or (2) age and salary in the same model did not alter core results.

${ }^{15}$ There is no simple, straightforward method for interpreting substantive effect in ordered probabilistic regressions (Dow 2008). However, graphing the results offers one of the more intuitive ways of conveying substantive significance. Predicted probabilities generated using margins and prgen commands in Stata v.11 and setting other variables at their means. Graphs generated using the rarea graphing option. See Long and Freese (2006); Stata Annotated Output Ordered Logistic Regression. UCLA: Academic Technology Services, Statistical Consulting Group. Available at: http://www.ats.ucla.edu/stat/stata/output/stata_ologit_output.htm (last accessed November 26, 2011).
} 
FIGURE 3

\section{PREDICTED PROBABILITY OF EGO'S ATTITUDE BY ALTERS' MEAN ATTITUDE}
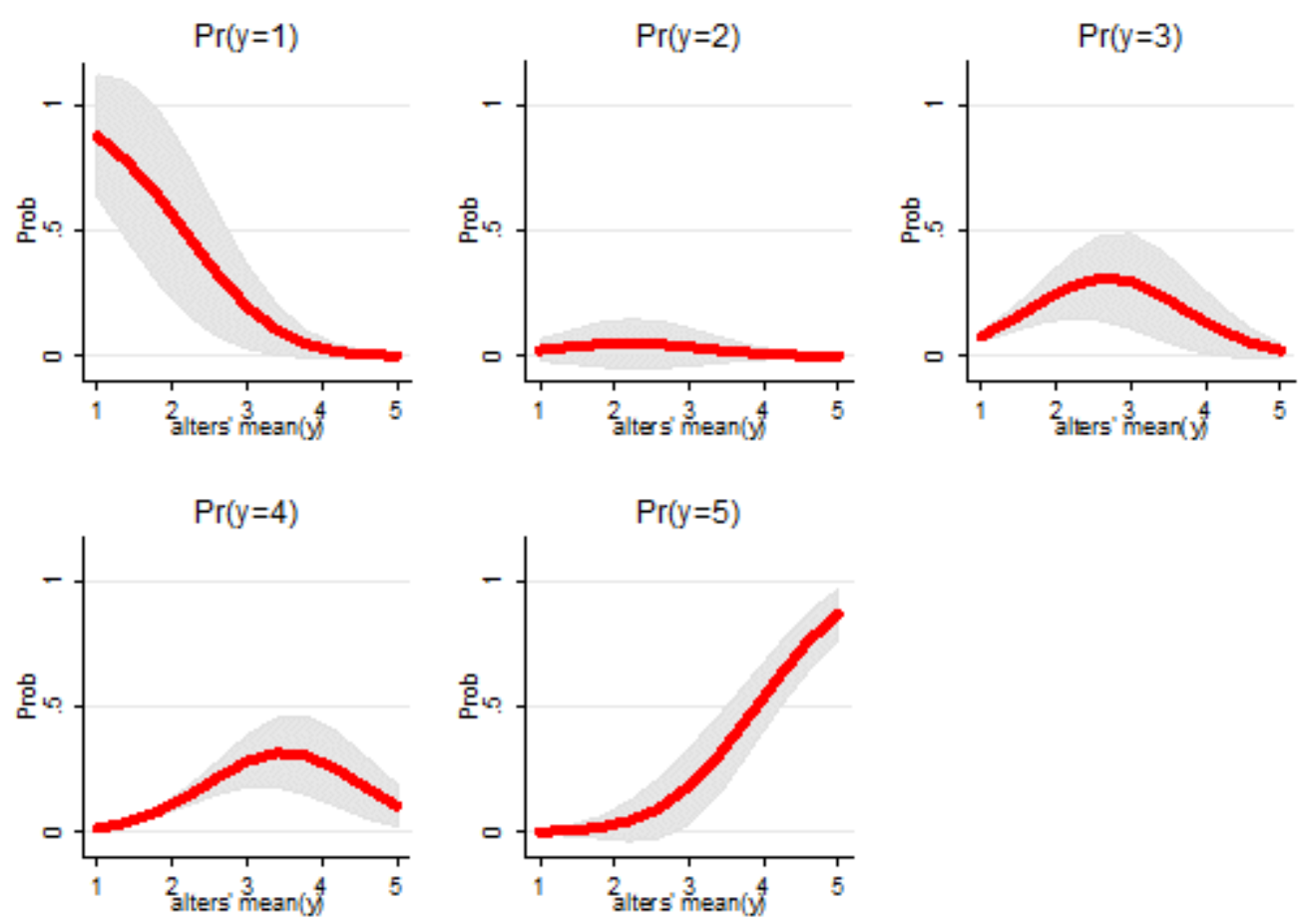

Results for other attitudes, including the criminal procedure reform of 2008, and jurisprudential attitudes - positivism and deference to higher courts - are in the online appendix. In each analysis, mean attitude among alters maintains its positive and statistically significant relationship with ego's attitude on the same issue. Further, it is worth noting that higher education levels have a negative and statistically significant relationship with positivism. That is, the traditionally formalistic, technical-legal approach to judging may be losing strength as more and more judges obtain graduate degrees. 
TABLE 5

\begin{tabular}{|c|c|c|c|c|c|c|}
\hline \multicolumn{7}{|c|}{$\begin{array}{l}\text { WHOLE NETWORK; ORDERED PROBABILISTIC REGRESSION } \\
\text { Y = ATTITUDES TOWARDS JUDICIAL COUNCILS (1-5) }\end{array}$} \\
\hline & 1 & 2 & 3 & 4 & 5 & 6 \\
\hline $\begin{array}{l}\text { Mean(y) for one-step } \\
\text { alters }\end{array}$ & $\begin{array}{l}0.43^{* *} \\
(0.14)\end{array}$ & $\begin{array}{l}0.47^{* *} \\
(0.14)\end{array}$ & $\begin{array}{l}0.46^{* *} \\
(0.14)\end{array}$ & $\begin{array}{l}0.35^{* *} \\
(0.15)\end{array}$ & $\begin{array}{l}0.48^{* *} \\
(0.14)\end{array}$ & $\begin{array}{l}0.42 * * \\
(0.15)\end{array}$ \\
\hline Degree & & $\begin{array}{l}-0.05 \\
(0.05)\end{array}$ & & & & $\begin{array}{l}0.03 \\
(0.05)\end{array}$ \\
\hline Betweenness & & & $\begin{array}{c}0.00 \\
(0.00)\end{array}$ & & & \\
\hline Closeness & & & & $\begin{array}{c}0.00 \\
(0.00)\end{array}$ & & \\
\hline Eigenvector & & & & & $\begin{array}{l}3.66 \\
(2.63)\end{array}$ & \\
\hline Female & & & & & & $\begin{array}{l}-0.36 \\
(0.26)\end{array}$ \\
\hline Magistrado & & & & & & $\begin{array}{c}-0.40 \\
(0.37)\end{array}$ \\
\hline Morelia $^{16}$ & & & & & & $\begin{array}{c}-0.21 \\
(0.28)\end{array}$ \\
\hline Number of obs & 102 & 102 & 102 & 102 & 102 & 102 \\
\hline LR chi2(4) & 11.98 & 12.93 & 14.38 & 15.49 & 14.00 & 16.75 \\
\hline Prob $>$ chi 2 & 0.0025 & 0.0048 & 0.0024 & 0.0014 & 0.0029 & 0.0102 \\
\hline Pseudo R2 & 0.0514 & 0.0554 & 0.0616 & .0664 & .0600 & 0.0718 \\
\hline \multicolumn{7}{|c|}{ Test of parallel regression assumption (should not be significant): } \\
\hline $\operatorname{chi} 2(12)$ & 2.48 & 4.50 & 4.26 & 2.92 & 3.48 & 18.96 \\
\hline Prob $>$ chi 2 & 0.87 & 0.88 & 0.89 & 0.97 & 0.94 & 0.3945 \\
\hline
\end{tabular}

\footnotetext{
${ }^{16}$ There are twenty-three judicial districts in the state. Initially, twenty-one dummies captured the districts individually (two districts were unrepresented in the data). However, only one district had any significance (Zinapecuaro) relating to a single judge, and there were no meaningful departures from the results here. Judicial districts were then collapsed into three categories: Morelia, west of Morelia, and east of Morelia. Again, there were no meaningful differences compared with the results here.
} 


\section{Results 2: Sociocentric Analysis}

Moving to the whole network data, Table 5 reports the regression results for attitudes regarding the judicial council. The key variable of interest - the mean attitude of all contacts one step away from each judge - has a positive coefficient across all models, providing general support for the proposition that a judge's attitude towards council reform increases as the attitude towards said reform increases among a judge's close colleagues. This result is also statistically significant across all models. Indeed, even controlling for various measures of centrality, homophily, and context, the result regarding direct contact remains.

It should be noted, however, that the analysis reported in Table 5 was conducted with network weights based on a valued adjacency matrix (W2). Additional analysis with a simple binary adjacency matrix (W1) yielded no statistically significant results (findings not reported here). Stated otherwise, the mere presence of a direct relation between ego and alter is not sufficient to influence ego's attitude; rather, the influence of direct relations is contingent on the strength or intensity of that relation. Thus, the sociocentric analysis generates no support for $\mathrm{H} 2$ but strong support for $\mathrm{H} 3$. The findings clearly complement the findings from the egocentric analysis, where both alters' mean attitude and tie strength mattered.

Turning to the other variables, none of the centrality measures have a statistically significant relationship with the respondent's attitude, so there is no support for H1. Therefore, the results support the conclusion that general social location (captured by centrality), in and of itself, matters less than the strength of direct relations. Measures of homophily (sex and position) are not consistently significant, but in several alternative specifications (not reported here), female has a negative relationship at the .10 level of significance. For instance, controlling for closeness centrality, judicial district, and position, female exerts a negative effect $(\mathrm{p}=0.08)$. Further, in all auxiliary models the coefficient for magistrado has a negative sign. Both of these results complement the findings from the egocentric analysis in the previous section.

Clarifying further, Figure 4 graphs predicted probabilities across response categories, setting the remaining variables at their means. As was the case with the prior 
egocentric analysis, each graph plots the predicted probability of each outcome (1-5; yaxis) against alters' mean attitude, weighted by the valued adjacency matrix (x-axis).

FIGURE 4

\section{PREDICTED PROBABILITY OF EGO'S ATTITUDE} AS A FUNCTION OF ALTERS' MEAN ATTITUDE
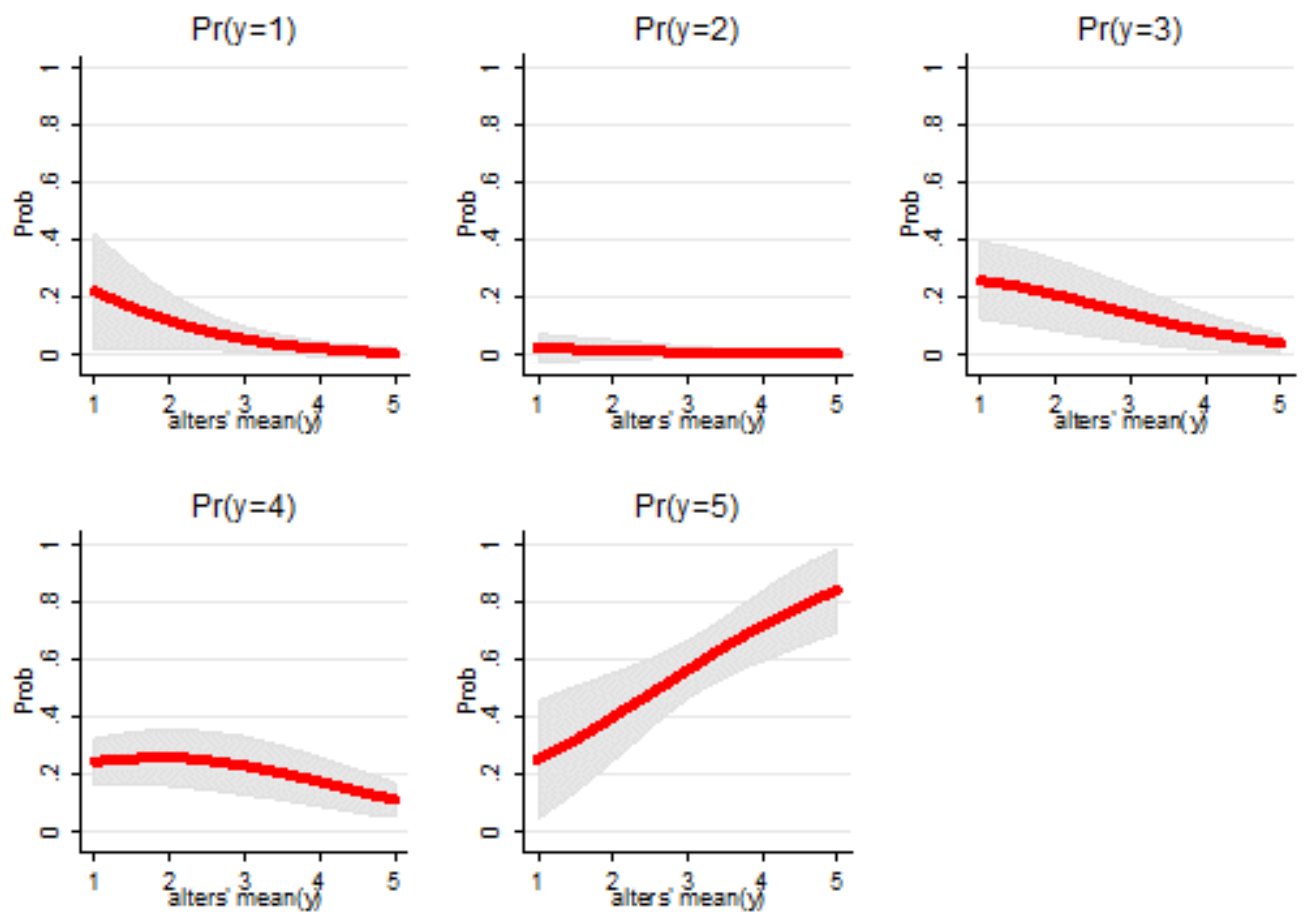

Two patterns should be highlighted from these graphs. First, the slope of the probability curves in the graphs supports the expected relationships. Specifically, in the first graph, it is more likely that ego will hold the most negative attitude towards judicial councils if her peers hold a negative attitude. Conversely, in the last graph, it is dramatically more likely that a judge will hold the most positive attitude towards judicial councils if her peers hold a positive attitude than if they hold the most negative attitude. Second, however, the relationship is only clearly significant for the highest value of the outcome variable. Thus, the evidence is still complementary of the egocentric analysis, but only for the highest value of the outcome variable. 
As a robustness check I applied a linear network autocorrelation model (Butts 2008). ${ }^{17}$ Linear network autocorrelation is not exactly appropriate given the ordinal response variable. Nonetheless, linear models generally yield robust results with ordinal variables, and results should at least be instructive. Various specifications of the network effects model (Butts 2008; Dow 2007) yielded results that were supportive of the core finding (results not reported here). Indeed, the findings were statistically more significant than the 2SCML methods detailed above, suggesting that the core results from the 2SCML reported in full above are the most conservative.

In sum, quantitative analyses of network diffusion for ego- and sociocentric data complement each other in showing that two factors influence ego's attitude: (1) alters' mean attitude, and (2) the strength of ties, i.e., the intensity of interactions.

\section{QUALITATIVE NETWORK ANALYSIS}

Triangulating further, qualitative methods yield additional insights regarding core findings from the quantitative analysis above and elucidate mechanisms of diffusion. The substantive part of the analysis addresses two issues - (1) external validity of network structure, and (2) validity of causal inferences - and draws on a set of five personal, indepth interviews with judges who participated in the survey generating the network data above. These judges are nodes 313, 2174, 2690, 3646, and 4635 in Figure 2.

Table 6 summarizes features of the interview sample. First, these five judges constitute low-residual observations, as evidenced by their "typicality" scores. ${ }^{18}$ All of the interview participants are in the top half of typicality scores, and two of them are in the top 10 percent. Thus, these are promising observations in which we might expect to find additional evidence of the central argument (Lieberman 2005). All observations are central according to various network measures. Further, the sample consists of four men and one woman, two judges from the interior of the state and three magistrados from the state capital, Morelia.

\footnotetext{
${ }^{17}$ Following Butts (2008), I employed lnam using the sna package in R.

${ }^{18}$ I follow Gerring and Seawright (2007) in calculating the absolute value of residuals, but given the ordinal level of measurement there is not as much variation in typicality. Therefore, I rank observations within each category by the predicted probability of the outcome, in essence yielding typicality scores ranked by the "confidence" in that typicality score.
} 
TABLE 6

FEATURES OF INTERVIEWEES

\begin{tabular}{|c|c|c|c|c|c|c|c|c|c|}
\hline ID & 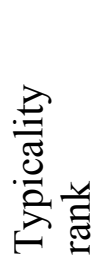 & 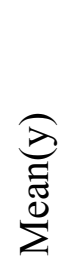 & 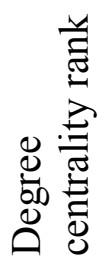 & 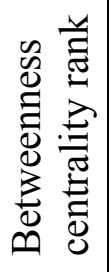 & 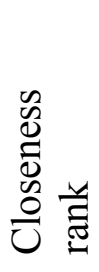 & 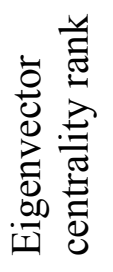 & $\begin{array}{l}凶 \\
\stackrel{\varpi}{\omega}\end{array}$ & $\begin{array}{l}\tilde{n} \\
0 \\
0\end{array}$ & $\frac{. \sqrt[\pi]{0}}{\stackrel{0}{0}}$ \\
\hline 313 & 8 & 4.6 & 3 & 4 & 1 & 1 & $\mathrm{M}$ & Juez & $\mathrm{N}$ \\
\hline 2174 & 18 & 5.0 & 2 & 1 & 2 & 3 & $\mathrm{~F}$ & Mag & $Y$ \\
\hline 2690 & 39 & 4.3 & 33 & 47 & 37 & 16 & $\mathrm{M}$ & Mag & $Y$ \\
\hline 3646 & 25 & 4.7 & 7 & 11 & 7 & 6 & $\mathrm{M}$ & Mag & $Y$ \\
\hline 4635 & 9 & 4.7 & 1 & 2 & 4 & 2 & $\mathrm{M}$ & Juez & $\mathrm{N}$ \\
\hline
\end{tabular}

In January 2012, six months after the administration of the survey, these judges were reminded of the questionnaire and shown a visualization of the judicial network for the full state as well as a visualization of the network for the state supreme court. They were then asked to focus on two questions: (1) whether the network structure reflected their own mental image of social relations among judges (external validity), and (2) what meaning they themselves attributed to those ties and the network structure now visualized.

Regarding external validity, 2174, 2690, and 3646 - all magistradosimmediately recognized the visualization of the STJ network as a fair representation of a split between primarily two groups of judges - a core group of more progressive judges spearheading changes in institutional design and jurisprudence. Each of these judges also spontaneously volunteered his or her guesses about which magistrados were part of the core group and which were more peripheral; a clear majority of these guesses were correct. Thus, the transition from questionnaire to network visualization appears to faithfully reproduce social structures that members of the court recognize in their daily interactions.

Beyond external validity, 2690 acknowledged that the individuals he listed as contacts in his discussion group are people he considers influential for his own way of thinking. He explicitly stated that these contacts shape the way he thinks about the law, 
legal conflicts, and institutional design. For instance, he noted an example in which he called one of his principal contacts, 1660, now retired and not included in the network, to discuss a particular legal matter and how the conversation with 1660 changed his perspective on the topic.

Similarly, 2174 noted that she feels influenced by those individuals with whom she is in contact. Asked specifically whether the people with whom she interacts most frequently_-her judicial discussion group — shaped her attitudes and ideas, she affirmed that this was the case. Over time and sustained interactions, she said, this group has come to have similar ideas. Pressed to give examples of this sort of phenomenon, 2174 noted that she relies on her discussion group contacts - and her contacts rely on her - for information and advice regarding novel legal issues that arise in cases and insights regarding institutional conflicts and political conflicts outside the judiciary that might affect the institution. For instance, regarding jurisprudential issues, 2174 recalled a conversation with one of her contacts in which she came to understand a particular legal concept from a different perspective. That is, judges might share entirely new legal concepts with each other, but they might also come to understand existing legal concepts from an entirely new vantage point.

Judges 313 and 4635 clarified this dynamic further. Both named 3646 as very influential in the way they think about both judicial councils and criminal procedure. Both also named 2714 as influential in the way they think about responsibility in criminal law. They mentioned the concepts of "dolo" and "culpa"- both of which are used to establish different degrees of culpability, or elements of "mens rea" in criminal offenses. These concepts generally have very strict and inflexible interpretations in Mexican law, but due to interactions with 2174 both judges came to adopt a more flexible interpretation of these concepts, particularly variations of "dolo." 19

Asked specifically whether they interacted frequently with 3646, 2174, or their other named contact due to shared ideas or whether they held similar ideas because of the frequency of interactions, both affirmed the latter. For instance, both 313 and 4635 were

\footnotetext{
19 "Dolo" is equivalent to deliberate criminal intent-intending to commit or allow an act to be committed knowing (or acknowledging the possibility) that said act is criminal—while "culpa" is equivalent to criminal negligence-unintentionally committing a crime out of recklessness or carelessness (see Zamora et al. 2004, 352-53).
} 
students of 3646 in law school, though in separate years, so they were exposed to 3646's ideas in academic settings and came to hold similar attitudes regarding legal issues. Further, they have both matured professionally under the mentorship of 2174, first working for her and then interacting with her as they ascended through different positions and district posts. The early professional contact with 2174 set the stage for sustained interaction over time, and both 313 and 4635 said they have come to adopt some of her ideas (e.g., regarding dolo, as noted above).

Separately, 313 and 4635 said they have both worked, at different times, in some of the most difficult districts in the state, including those districts where organized crime has a strong presence (e.g., Lázaro Cárdenas and Apatzingán). While judges in these districts, they faced bribe attempts and complex legal cases and also had to coexist alongside witnesses, victims, and offenders in communities heavily populated with individuals connected to organized crime. They were able to successfully navigate these challenges, and as a result colleagues seek them out for advice when faced with similar situations. This, they said, may account for their prominence in the network.

In sum, the interview evidence supports the network influence finding from the statistical analysis, adding context and depth regarding certain structural features of the network. Further, regarding mechanisms of diffusion, interviews identified academic and professional mentorship relations as mechanisms underlying the diffusion profession. Indeed, since most judges in Michoacán come from the state's main public law school (following a pattern seen across the Mexican states), professors in these institutions who are concurrently or subsequently also judges may be particularly influential. This insight resonates with Katz et al.'s (2011) findings regarding the "infectiousness of ideas" among law professors and clerks.

\section{CONCLUSIONS AND IMPLICATIONS}

The project makes three core contributions. First, I contribute original data based on a survey of these judges. These data cover a wide range of judicial attitudes, as well as structural properties of judicial networks. The data demonstrate that network-oriented research with original surveys is feasible with "hard-to-reach" populations such as judges 
in less developed settings, even where there are substantial security considerations. Second, the network batteries of the survey yield egocentric data, and these egocentric data can be aggregated to form sociocentric data at three levels of analysis: judicial district, state supreme court, and entire state. Finally, a mixed-methods causal analysiscombining two forms of quantitative analysis in addition to in-depth interviews-yields consistent findings regarding the diffusion of ideas across judicial networks.

Concretely, I find that ideas diffuse among judges who are in intense interaction with each other. This finding is supported by analysis of egocentric data, showing that the mean attitude of a judge's close contacts shapes that judge's own attitudes and that the strength of ties also contributes to ego's attitude. Aggregating the egocentric data to form sociocentric data at the level of the entire state and applying different techniques, I find complementary evidence that strong, direct interaction with one's colleagues shapes judges' attitudes. These findings hold while controlling for a range of other network variables, demographic characteristics, and context.

In the future, this project aims to expand to other states and countries in order to gather additional data on judicial networks, test the generalizability of arguments, and measure different kinds of legal networks. Whether the findings reported here hold across different policy areas — institutional and jurisprudential — is also a question of major interest. Additional research questions regarding tie formation and tie degradation offer compelling prospects for the future.

Overall, the findings are broadly suggestive of a relationship between structure and agency. If social structure has a powerful influence over ideas and behavior, then agency may not always be a fully conscious, deliberative phenomenon, as work on "satisficing" and mental shortcuts has suggested (Simon 1985). ${ }^{20}$ Nonconscious influences have deep implications for the nature of the relationship between structure and agency across multiple arenas, including rationalist, decision-theoretic approaches to behavior. Beyond cognitive shortcuts, however, our individual decisions are not

\footnotetext{
${ }^{20}$ The debate over conscious and nonconscious cognitive processes also has roots in the social movements literature. For instance, the framing of ideas, identities, or other nonmaterial reasons for joining a movement may be nonconscious or not fully formed consciously at early movement stages; however, once the movement is established, framing and messaging become much more conscious and strategic (McAdam, McCarthy, and Zald 1996, 6, 16).
} 
independent of other individuals; they are imbedded in a dependent web of relations. Thus, what appears to be an individualistic, conscious decision may in fact be the result of the nonconscious influence of social structure. Put simply if crudely, whom we know affects what we know, and without us even knowing it!

On a more practical level, the findings have concrete policy implications for the judicial leadership in states like Michoacán. Trainings and other fora where judges can interact and share ideas are ripe environments in which to bring judges in contact with new ideas or expose judges, clerks, and other staff to new ways of thinking. Judicial leaders have great control over who is invited to speak at these events. Perhaps more importantly, judicial leaders have control over how frequently and intensely judges interact in these events. For instance, are these events lectures or more interactive, engaging kinds of activities? Beyond trainings and formal settings, how do judges interact informally, perhaps even outside the workplace? Are there smaller settings or activities in which judges can be selectively invited to exchange ideas with judicial leaders, academics, or even prominent judges from other jurisdictions? Can judges be encouraged to attend particular conferences or workshops? Also, can judicial leaders leverage information on the centrality of individual colleagues to affect the flow and diffusion of ideas, inviting very central individuals to small-group sessions on new or proposed reforms or, conversely, inviting peripheral individuals to larger sessions or sessions led by more central individuals? Answers to each of these questions will depend on local conditions and capabilities, but these are the kinds of policy implications that flow from the results. 


\section{REFERENCES}

Amaral-Garcia, Sofia, Nuno Garoupa, and Veronica Grembi. 2009. "Judicial Independence and Party Politics in the Kelsenian Constitutional Courts: The Case of Portugal." Journal of Empirical Legal Studies 6 (2) (June): 381-404.

Beer, Caroline C. 2003. Electoral Competition and Institutional Change in Mexico. Notre Dame: University of Notre Dame Press.

Berardo, Ramiro. 2011. "Networking Networkers: An Initial Exploration of the Patterns of Collaboration among the Members of a New Community in Political Science." PS: Political Science (January): 69-75.

Borgatti, S. P., M. G. Everett, and L. C. Freeman. 1999. UCINET 6.0 Version 1.00. Natick: Analytic Technologies.

Brewer, J., and A. Hunter. 1989. Multimethod Research: A Synthesis of Styles. Newbury Park: SAGE Publications.

Burt, Ronald S. 1984. "Network Items and the General Social Survey." Social Networks 6: 293-339.

_. 1987. "Social Contagion and Innovation: Cohesion versus Structural Equivalence." American Journal of Sociology 92: 1287-1335.

Butts, Carter T. 2008. "Social Network Analysis with sna.” Journal of Statistical Software 24 (6): 1-51.

Carbonell, Miguel, ed. 2003. Neoconstitucionalismo(s). Madrid: Trotta.

Cárdenas, Rodolfo Félix, Alejandro González Gómez, Moises Moreno Hernandez, Elia Patricia Neri Guajardo, and Miguel Ontiveros Alonso, eds. 2010. Derecho Penal y Política Criminal: Libro en homenaje al Maestro Álvaro Bunster. Mexico City: Editorial UBIJUS and Instituto de Formación Profesional.

Chavez, Rebecca Bill. 2004. Rule of Law in Nascent Democracies: Judicial Politics in Argentina. Stanford: Stanford University Press.

Couso, Javier. 2010. "The Transformation of Constitutional Discourse and the Judicialization of Politics in Latin America." In Javier Couso, Alexandra Huneeus, and Rachel Sieder, eds., Cultures of Legality: Judicialization and Political Activism in Latin America, 141-160. New York: Cambridge University Press. 
Couso, Javier, and Lisa Hilbink. 2011. "From Quietism to Incipient Activism: The Institutional and Ideational Roots of Rights Adjudication in Chile." In Gretchen Helmke and Julio Ríos-Figueroa, eds., Courts in Latin America, 99-127. New York: Cambridge University Press.

Couso, Javier, Alexandra Huneeus, and Rachel Sieder. 2010. Cultures of Legality: Judicialization and Political Activism in Latin America. New York: Cambridge University Press.

Cumaraswamy, D. P. 2002. Independence of the Judiciary, Administration of Justice, Impunity: Report on the Mission to Mexico. Report of the Special Rapporteur on the Independence of Judges and Lawyers, Economic and Social Council of the United Nations. Submitted in accordance with Commission on Human Rights resolution 2001/39.

Danowski, J.A. 1986. "Interpersonal Network Structure and Media Use: A Focus on Radiality and Non-Mass Media Use." In G. Gumpert and R. Cathcart, eds. Intermedia, 3rd ed., 168-175. New York: Oxford University Press.

Denzin, Norman K. 1978. “The Logic of Naturalistic Inquiry.” In N. K. Denzin, ed., Sociological Methods: A Sourcebook, 54-73. New York: McGraw-Hill.

Desposato, Scott, Matthew C. Ingram, and Osmar P. Lannes. 2011. "Changing Patterns of Judicial Behavior in Civil Law Systems: Decisions on Brazil's Supremo Tribunal Federal." Paper presented at the annual meeting of the Law and Society Association.

Dow, Malcolm. 1979. Structure and Process in Cultural-Ecological Complexes. Unpublished doctoral thesis, University of California at Irvine.

Dow, Malcolm. 1984. A Bi-Parametric Approach to Network Autocorrelation: Galton's Problem. Sociological Methods and Research 13: 201-217.

Dow, Malcolm M. 2007. "Galton's Problem as Multiple Network Autocorrelation Effects: Cultural Trait Transmission and Ecological Constraint." Cross-Cultural Research 41 (4): 336-63.

. 2008. "Network Autocorrelation Regression with Binary and Ordinal Dependent Variables: Galton's Problem." Cross-Cultural Research 42 (4): 394-419.

Dow, Malcolm M., M. L. Burton, and D. R. White. 1982. "Network Autocorrelation: A Simulation Study of a Foundational Problem in Regression and Survey Study Research." Social Networks 4: 169-200. 
Engelmann, Fabiano. 2004. "Diversificação do espaço jurídico e lutas pela definição do direito no Rio Grande do Sul.” PhD diss., Institute of Human Sciences, Graduate Program in Political Science, Federal University of Rio Grande do Sul (UFRGS), Brazil.

- 2007. "Tradition and Diversification in the Uses and Definitions of the Law: A Proposed Analysis.” Brazilian Political Science Review 1 (1): 53-70.

Epp, Charles. 1998. The Rights Revolution: Lawyers, Activists, and Supreme Courts in Comparative Perspective. Chicago: University of Chicago Press.

Fariss, Christopher J., and Keith E. Schnakenberg. 2009. “A Human Rights Network Influences Countries' Torture Policies.” Working Paper, Political Networks Working Paper Archive. Available at http://opensiuc.lib.siu.edu/pn wp/24 (accessed March 2, 2012).

Ferrajoli, Luigi, and Juan Ruiz Manero. 2012. Dos modelos de constitucionalismo: Una conversación. Madrid: Trotta.

Ferree, Myra Marx, and Frederick D. Miller. 1977. "Winning Hearts and Minds: Some Psychological Contributions to the Resource Mobilization Perspective on Social Movements." Unpublished paper.

Finkel, Jodi. 2008. Judicial Reform as Political Insurance. Notre Dame: University of Notre Dame Press.

Fix-Fierro, Héctor. 2003. "Judicial Reform in Mexico: What Next?" In Erik G. Jensen and Thomas C. Heller, eds., Beyond Common Knowledge: Empirical Approaches to the Rule of Law, 240-89. Stanford: Stanford University Press.

_. 2004. "La reforma en México: Entre la eficacia autoritaria y la incertidumbre democrática." In Luis Pásara, ed., En busca de una justicia distinta: Experiencias de reforma en América Latina, 249-87. Mexico City: Instituto de Investigaciones Jurídicas, UNAM.

Fix-Zamudio, Héctor, and Héctor Fix-Fierro. 1996. "El Consejo de la Judicatura." Cuadernos para la Reforma de la Justicia 3. Mexico City: Instituto de Investigaciones Jurídicas, UNAM. Available at http://www.bibliojuridica.org/libros/libro.htm?l=86 (accessed March 2, 2008).

Fowler, James H., Michael T. Heaney, David W. Nickerson, John F. Padgett, and Betsy Sinclair. 2011. "Causality in Political Networks." American Politics Research 39 (2): 437-80.

Fowler, James H., and Sangick Jeon. 2008. "The Authority of Supreme Court Precedent." Social Networks 30 (1): 16-30. 
Fowler, James H., Timothy R. Johnson, James F. Spriggs II, Sangick Jeon, and Paul J. Wahlbeck. 2007. "Network Analysis and the Law: Measuring the Legal Importance of Supreme Court Precedents." Political Analysis 15 (3): 324-46.

Gerring, John, and Jason Seawright. 2007. "Case-Selection Techniques in Case Study Research: A Menu of Qualitative and Quantitative Options.” In John Gerring, Case Study Research: Principles and Practices, Ch. 7. Cambridge: Cambridge University Press.

Gillman, Howard. 2002. "How Political Parties Can Use the Courts to Advance Their Agendas: Federal Courts in the United States, 1875-1891." American Political Science Review 96: 511-24.

- 2008. "Courts and the Politics of Partisan Coalitions." In Keith E. Whittington, R. Daniel Kelemen, and Gregory A. Caldeira, eds., The Oxford Handbook of Law and Politics, 644-62. Oxford: Oxford University Press.

González Gómez, Alejandro. 2007. Estudios Penales y Jurídicos. Mexico City: Editorial UBIJUS.

Hanneman, Robert A., and Mark Riddle. 2005. Introduction to Social Network Methods. University of California, Riverside. Available at: http://www.faculty.ucr.edu/ hanneman/nettext.

Hilbink, Lisa. 2007a. Judges beyond Politics in Democracy and Dictatorship: Lessons from Chile. New York: Cambridge University Press.

- 2007b. "Politicising Law to Liberalise Politics: Anti-Francoist Judges and Prosecutors in Spain's Democratic Transition.” In Terence C. Halliday, Lucien Karpik, and Malcolm M. Feeley, eds., Fighting for Political Freedom:

Comparative Studies of the Legal Complex and Political Liberalism, 403-437. Portland, OR: Hart Publishing. . 2009. "The Constituted Nature of Constituents' Interests: Historical and Ideational Factors in Judicial Empowerment.” Political Research Quarterly 62 (4) (December): 781-797.

—. Forthcoming 2012. "The Origins of Positive Judicial Independence." World Politics 44 (4).

Hirschl, Ran. 2000. "The Political Origins of Judicial Empowerment through Constitutionalization: Lessons from Four Constitutional Revolutions." Law \& Social Inquiry 25 (1) (Winter): 91-149.

Hirschl, Ran. 2004. Towards Juristocracy: The Origins and Consequences of the New Constitutionalism. Cambridge: Harvard University Press. 
Hollstein, Bettina. 2011. "Qualitative Network Analysis.” In James Scott and Peter J. Carrington, eds., Sage Handbook of Social Network Analysis, 404-416. London and New Delhi: Sage.

Huckfeldt, Robert, and John Sprague. 1987. "Networks in Context: The Social Flow of Political Information.” American Political Science Review 87 (4, December): 1197-1216.

- 1993. "Citizens, Contexts, and Politics.” In Ada W. Finifter, ed., Political Science: The State of the Discipline II, 281-303. Washington, DC: American Political Science Association.

Ingram, Matthew C. 2009. "Crafting Courts in New Democracies: The Politics of Subnational Judicial Reform in Brazil and Mexico.” PhD diss., Department of Political Science, University of New Mexico.

_. 2012a. "El estado de los estados; Reformas locales al procedimiento penal en México." In David A. Shirk and Octavio Rodriguez, eds., La reforma del sistema de justicia penal en México. San Diego: Trans-Border Institute, University of San Diego, and University Readers.

- 2012b. "Crafting Courts in New Democracies: Ideology and Judicial Council Reforms in Three Mexican States.” Comparative Politics 44 (4, July): 439-458.

Ingram, Matthew C., Octavio Rodriguez Ferreira, and David A. Shirk. 2011. Justiciabarómetro. San Diego: Trans-Border Institute.

Ingram, Matthew C., and David A. Shirk. 2010. "Judicial Reform in Mexico: Toward a New Criminal Justice System.” Special Report (May), Trans-Border Institute, University of San Diego. Available at justiceinmexico.org/publications/justice-inmexico-project.

Kapiszewski, Diana. 2011b. "Tactical Balancing: High Court Decision-Making on Politically Crucial Cases." Law and Society Review 45 (2): 471-506.

Katz, Daniel Martin, Joshua Gubler, Jon Zelner, Michael James Bommarito, Eric A. Provins, and Eitan M. Ingall. 2011. "Reproduction of Hierarchy? A Social Network Analysis of the American Law Professoriate." Journal of Legal Education 61 (1): 1-28.

Katz, Daniel Martin, and Derek K. Stafford. 2010. "Hustle and Flow: A Social Network Analysis of the American Federal Judiciary." Ohio State Law Journal 71 (3): 457-507. 
Kelejian, H. H., and I. R. Prucha. 1998. "A Generalized Spatial Two-Stage Least Squares Procedure for Estimating a Spatial Autoregressive Model with Autoregressive Disturbances." Journal of Real Estate Finance and Economics 17: 99-121.

Langer, Máximo. 2007. "Revolution in Latin American Criminal Procedure: Diffusion of Legal Ideas from the Periphery." American Journal of Comparative Law 55: 617 676.

Leenders, Roger Th. A. J. 2002. "Modeling Social Influence through Network Autocorrelation: Constructing the Weight Matrix." Social Networks 24: 21-47.

Lieberman, Evan S. 2005. "Nested Analysis as a Mixed-Method Strategy for CrossNational Research." American Political Science Review 99: 435-52.

Long, J. Scott, and Jeremy Freese. 2006. Regression Models for Categorical Dependent Variables Using Stata. College Station, TX: Stata Press.

Lupu, Yonatan, and Erik Voeten. 2012. "Precedent in International Courts: A Network Analysis of Case Citations by the European Court of Human Rights." British Journal of Political Science 42: 413-39.

McAdam, Doug, John D. McCarthy, and Mayer N. Zald. 1996. "Introduction: Opportunities, Mobilizing Structures, and Framing Processes-Toward a Synthetic, Comparative Perspective on Social Movements.” In Doug McAdam, John D. McCarthy, and Mayer N. Zald, eds., Comparative Perspectives on Social Movements, 1-20. New York: Cambridge University Press.

McCann, Michael W. 1994. Rights at Work: Pay Equity Reform and the Politics of Legal Mobilization. Chicago: University of Chicago Press.

Martin, Andrew D., and Kevin M. Quinn. 2002. "Dynamic Ideal Point Estimation via Markov Chain Monte Carlo for the U.S. Supreme Court, 1953-1999." Political Analysis 10 (2): 134-153.

_ 2007. "Assessing Preference Change on the U.S. Supreme Court." Journal of Law, Economics, and Organization 23 (2): 365385.

Miller, G.A. 1956. "The Magical Number Seven Plus or Minus Two: Some Limits on Our Capacity for Processing Information." Psychological Review 63: 81-97.

Müller, Christoph, Barry Wellman, and Alexandra Marin. 1999. "How to Use SPSS to Study Ego-Centered Networks." Bulletin de méthodologies sociologiques 64: 6376.

Nunes, Rodrigo. 2010. "Ideational Origins of Progressive Judicial Activism.” Latin American Politics and Society 52 (3): 67-97. 
O'Donnell, Guillermo. 2001. "Democracy, Law, and Comparative Politics.” Studies in International Comparative Development 36 (1): 5-36. Longer version previously appeared as Working Paper No. 274, Helen Kellogg Institute for International Studies, University of Notre Dame; available at: kellogg.nd.edu.

Rodríguez-Garavito, César. 2011. "Toward a Sociology of the Global Rule of Law Field: Neoliberalism, Neoconstitutionalism, and the Contest over Judicial Reform in Latin America." In Yves Dezalay and Bryant Garth, eds., Lawyers and the Rule of Law in an Era of Globalization, 155-181. New York: Routledge.

Sánchez, Arianna, Beatriz Magaloni, and Eric Magar. 2011. "Legalist versus Interpretativist: The Supreme Court and the Democratic Transition in Mexico." In Gretchen Helmke and Julio Ríos-Figueroa, eds. Courts in Latin America, 187218. New York: Cambridge University Press.

Segal, Jeffrey A., and Albert D. Cover, 1989. "Ideological Values and the Votes of U.S. Supreme Court Justices.” American Political Science Review 83 (2): 557-65.

Segal, Jeffrey, and Harold Spaeth. 2002. The Supreme Court and the Attitudinal Account Revisited. Cambridge: Cambridge University Press.

Simon, Herbert A. 1974. "How Big Is a Chunk?” Science 183: 482-88.

—. 1985. "Human Nature in Politics: The Dialogue of Psychology with Political Science.” American Political Science Review 79: 293-304.

Smoot, Michael, Keiichiro Ono, Johannes Ruscheinski, Peng-Liang Wang, and Trey Ideker. 2011. "Cytoscape 2.8: New Features for Data Integration and Network Visualization." Bioinformatics 27 (3): 431-32 (published online December 12, 2010; http://www.cytoscape.org).

Snyder, Richard. 2001. "Scaling Down: The Subnational Comparative Method." Studies in Comparative International Development 36 (1) (Spring): 93-110.

Sokhey, Anand E., and Paul A. Djupe. 2011. "Interpersonal Networks and Democratic Politics.” PS: Political Science (January): 55-59.

Sunstein, Cass R., David Schkade, and Lisa Michelle Ellman. 2004. "Ideological Voting on Federal Courts of Appeals: A Preliminary Investigation." Virginia Law Review 90: 301-354.

Sunstein, Cass R., David Schkade, Lisa M. Ellman, and Andres Sawicki. 2006. Are Judges Ideological? An Empirical Analysis of the Federal Judiciary. Washington, DC: Brookings Institution Press. 
Tarrow, Sidney. 1995. "Bridging the Quantitative-Qualitative Divide in Political Science." American Political Science Review 89: 471-74.

Tashakkori, Abbas, and Charles Teddlie. 1998. Mixed Methodology: Combining Qualitative and Quantitative Approaches. Thousand Oaks: SAGE Publications.

United Nations Development Programme (UNDP). 2004. Democracy in Latin America: Towards a Citizens' Democracy. New York; available at: www.undp.org.

Valente, Thomas W. 1995. Network Models of the Diffusion of Innovations. Cresskill, NJ: Hampton Press.

Wasserman, Stanley, and Katherine Faust. 1994. Social Network Analysis: Methods and Applications. Cambridge: Cambridge University Press.

Woods, Patricia. 2008. Judicial Power and National Politics: Courts and Gender in the Religious-Secular Conflict in Israel. Albany: SUNY Press.

- 2009. "The Ideational Foundations of Israel's 'Constitutional Revolution'.” Political Research Quarterly 62 (4) (December): 811-24.

Woods, Patricia J., and Lisa Hilbink. 2009. "Comparative Sources of Judicial Empowerment: Ideas and Interests." Political Research Quarterly 62 (4) (December): 745-52.

Zamora, Stephen, José Ramón Cossío, Leonel Pereznieto, José Roldán-Xopa, and David Lopez. 2004. Mexican Law. Oxford: Oxford University Press. 